\title{
Veri zarflama analizi ile sağlık alanında bir performans değerlendirmesi
}

\section{A performance assessment in the field of health with data envelopment analysis}

\author{
Pelin KASAP $* 1, a$, Fikretcan GÜÇ, \\ ${ }^{1}$ Ondokuz Mayıs Üniversitesi, Fen Edebiyat Fakültesi, İstatistik Bölümü, Samsun \\ ${ }^{2}$ Giresun Il Milli Ĕ̈itim Müdürlüğ̈̈, Teyyaredüzü Ortaokulu, Giresun
}

• Geliş tarihi / Received: 14.02.2021 • • Düzeltilerek geliş tarihi / Received in revised form: 01.12.2021 • Kabul tarihi / Accepted: 01.01 .2022

\section{$\ddot{O} z$}

Veri zarflama analizi, son yıllarda bankacılık, sağlık, eğitim gibi sektörlerde performans değerlendirmesi için yaygın olarak kullanılmaktadır. Bu araştırmada Samsun Ondokuz Mayıs Üniversitesi Eğitim ve Araştırma Hastanesi bünyesinde faaliyet gösteren anabilim dallarının etkinlik değerlerinin belirlenmesi amacıyla parametrik olmayan etkinlik analiz metotlarından veri zarflama analizi uygulanmıştır. Analizler girdi ve çıtı yönelimli olmak üzere Charnes-Cooper-Rhodes ve Banker-Charnes-Cooper modelleri ile yapılmıştır. Bu hususta 2018 yılı kapsamında Ocak ve Kasım ayları da dahil olmak üzere 11 ay boyunca hizmet veren aktif ve yatan hastalar için servisleri bulunan polikliniklere sahip 27 anabilim dalı araştırma kapsamına dahil edilmiştir. Mevcut veri seti iki farklı model (Banker-Charnes-Cooper, Charnes-CooperRhodes) ve bu modellere bağlı dört farklı alt model (Girdi yönlü Banker-Charnes-Cooper, çıktı yönlü Banker-CharnesCooper, girdi yönlü Charnes-Cooper-Rhodes ve çıktı yönlü Charnes-Cooper-Rhodes) kullanılarak analiz edilmiş olup, anabilim dallarına ait etkinlik değerleri ortaya konulmuştur. Sonuç olarak, incelenen dört modelde de 11 anabilim dalının etkin halde olduğu görülmüştür.

Anahtar kelimeler: BCC modeli, CCR modeli, Veri zarflama analizi

\begin{abstract}
Data envelopment analysis has been widely used for performance evaluation in sectors such as banking, health, education in recent years. In this study, data envelopment analysis, one of the non-parametric efficiency analysis methods, has applied in order to determine the efficiency values of the departments operating within Samsun Ondokuz Mayls University Training and Research Hospital. Analyzes have performed using input and output oriented Charnes-Cooper-Rhodes and Banker-Charnes-Cooper models. In this regard, 27 departments with outpatient clinics with services for active and inpatients, which serve for 11 months, including January and November, have included in the scope of the study. The current data set has analyzed using two different models (Charnes-Cooper-Rhodes and Banker-Charnes-Cooper) and four different sub-models connected to these models (input oriented Banker-Charnes-Cooper, output oriented BankerCharnes-Cooper, input oriented Charnes-Cooper-Rhodes and output oriented Charnes-Cooper-Rhodes), and the efficiency values of the departments were revealed. As a result, 11 departments are found to be active in all four models examined.
\end{abstract}

Keywords: BCC model, CCR model, Data envelopment anlysis

\footnotetext{
*a Pelin KASAP; pelin.kasap@omu.edu.tr, Tel: (0362) 31219 19-5237, orcid.org/0000-0002-1106-710X

${ }^{\mathrm{b}}$ orcid.org/0000-0001-5303-9425
} 


\section{Giriş \\ 1. Introduction}

Performans sözcüğünün Fransızca'dan dilimize katılmasıyla farklı tanımlamaları yapılmıştır. $\mathrm{Bu}$ tanımlamalardan birinde şu şekilde ifade edilmektedir: İş gören kişinin kendisine belirli sınırlamalar ile ifade edilmiş işi, kendi yetenek ve özellikleri doğrultusunda ortaya çıkartması olarak tanımlanmıştır (Erdoğan, 1991). Bir başka tanımlamada ise, bir işi gerçekleştirecek olan kişi, topluluk veya kurumun o iş ile ilgili hedeflerine yönelik olarak neleri gerçekleştirebildiğinin nicel ve nitel olarak ifadesidir şeklinde tanımlanmıştır (Baş \& Artar, 1990). Tanımlamalar 1şı̆̆ında performans, bir işin ulaşılmak istenen sonucunun genel hatlarıyla belirlenerek, belirlenen hedeflere ulaşma durumu olarak ifade edilebilir.

Performans değerlendirme, bir organizasyonun önceden planlanmış hedeflere uygun bir şekilde uygulanması ve istenen hedeflere ulaşma seviyesi olarak tanımlamıştır (Timur, 2001).

Performans değerlendirmenin organizasyona sağlayacağı kazanımlar aşağıdaki gibi sıralanabilir (Uyargil, 1994; Erdoğan, 1991);

- Performans değerlendirmesi, ortaya konulan iş ve çalışanlar hakkında yönetime önemli bilgiler sağlar. İşin ve kişinin anlaşılmasına olanak tanir.

- Çalışan ve yöneticiler arasında iş ile ilgili beklentiler ve işin sonuçları ile ilgili bir kaliteli bir diyalog süreci kurulduğunda yeni yöntem ve fikirlerin kullanımına olanak sağlar.

- Organizasyonun vizyon ve misyonunun ortaya konulmasını sağlar.

- Organizasyonda faaliyet gösterecek birimlerin belirlenmesine yardımcı olur.

- Yüksek performansli bireylerin ödüllendirilmesini sağlayacak ve objektifliği kolaylaştıracaktır. Bunun yanında maaş standardizasyonunu sağlamada da etkin olacaktır.

- Çalışanların terfi işlemleri daha net ve kolay bir hal alacaktır.

Barutçugil (2002) performans değerlendirme sürecinin amaçlarını şu şekilde özetlemiştir; performansı açıklamak, ödüllendirmek, geliştirmek ve bekleneni veremeyen çalışanların kendini geliştirmesini sağlamak, çalışanlar hakkında ve işleri hususunda net ve doğru bilgilere sahip olmak, çalışanlara performansları ile ilgili geri bildirimler sunmak, çalışanların beklentilerine karşılık vererek endişelerini giderip, bilinmezlikleri ortadan kaldırmak, performansı yeterli olmayan çalışanların performanslarını artırıcı hamleleri yaparken, çözüm yollarını çalışanlar ile birlikte belirlemek ve örgütsel problemlerin belirlenmesinde yardımcı olmaktır.

Yaklaşımlara göre değișen performans tanımlarından yola çıkılarak farklı dönemlerde farklı performans boyutları ortaya konulmuştur. Bunlardan en çok karıştırılan ve kullanılan etkinlik, etkililik ve verimlilik kavramlarıdır. Etkinlik, var olan kaynakların en uygun şekilde tüketilerek elde edilebilecek en iyi çıktının ortaya çıkarılmasıdır (Yükçü \& Atağan, 2009). Etkililik, bir organizasyonun daha önceden belirlemiş olduğu amaç ve hedeflere ulaşmak için uyguladıkları eylemler sonucunda hedeflerine ne derecede ulaşabildiğinin ölçülmesidir (Bakırer, 2016).

Bir organizasyon etkin iken etkili çalışmayabilir. Yani, bu organizasyon kaynaklarını en iyi şekilde kullanarak çıktı elde etmiş ve etkin olmuş olabilir, ancak bu çıktı önceden planlanan hedefin altında kaldığından dolayı etkili olmayabilir (Yükçü \& Atağan, 2009).

Tablo 1. Çeşitli etkinlik ve etkililik birleşim durumları (Yükçü \& Atağan, 2009).

Table 1. Various combinations of efficiency and effectiveness (Yükçü \& Atağan, 2009).

a) Etkinlik: Kaynak Kullanımı

\begin{tabular}{|c|c|c|}
\hline \multirow{3}{*}{ 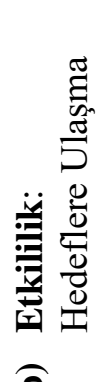 } & $(\mathbf{a}=-, \mathbf{b}=-)$ & $(a=-, b=+)$ \\
\hline & $\begin{array}{l}\text { Hem etkili değil, hem de etkin değil. Ne } \\
\text { hedeflerine ulaşabiliyor ne de kaynaklar1 } \\
\text { doğru kullanabiliyor. }\end{array}$ & $\begin{array}{l}\text { Etkili fakat etkin değil. Kaynak kullanımı } \\
\text { kötü olmasına rağmen yine de hedeflerine } \\
\text { ulaşmış. }\end{array}$ \\
\hline & $(a=+, b=-)$ & $(a=+, b=+)$ \\
\hline 2 & $\begin{array}{l}\text { Etkin fakat etkili değil. Hedeflere } \\
\text { ulaşamamakla birlikte kaynak kullanımı iyi. }\end{array}$ & $\begin{array}{l}\text { Etkili ve etkin. Hedeflere ulaşıyor, } \\
\text { kaynaklar iyi kullaniliyor ve yüksek } \\
\text { performans sergileniyor. }\end{array}$ \\
\hline
\end{tabular}


Etkililik (hedeflere ulaşma) başarı için ön koşuldur, etkinlik (kaynak kullanımı) ise bu başarıyı güçlendiren bir faktördür. İşletmelerin amacı bütün faaliyetlerinde etkililiği sağlamak, etkili olmayan tüm faaliyetleri etkinliği ne kadar fazla olursa olsun azaltmak veya elemek olmalıdır (Yükçü \& Atağan, 2009).

Verimlilik, bir üretim veya hizmet organizasyonunun ürettiği çıktı ile bu çıktıyı meydana getirmek için harcanan girdi arasındaki ilişkidir (Prokopenko, 1998).

Verim ise bir üretimin gerçekleşmesi sırasında üretim kaynaklarının en uygun şekilde kullanımını gösteren bir performanstır. Bundan dolayı verim, kaynak tüketimi ile ilgilidir (Gülcü vd, 2004). Verim ile verimlilik arasındaki ilişki Şekil 1'de ifade edilmiştir.

\section{S ÜR E Ç}

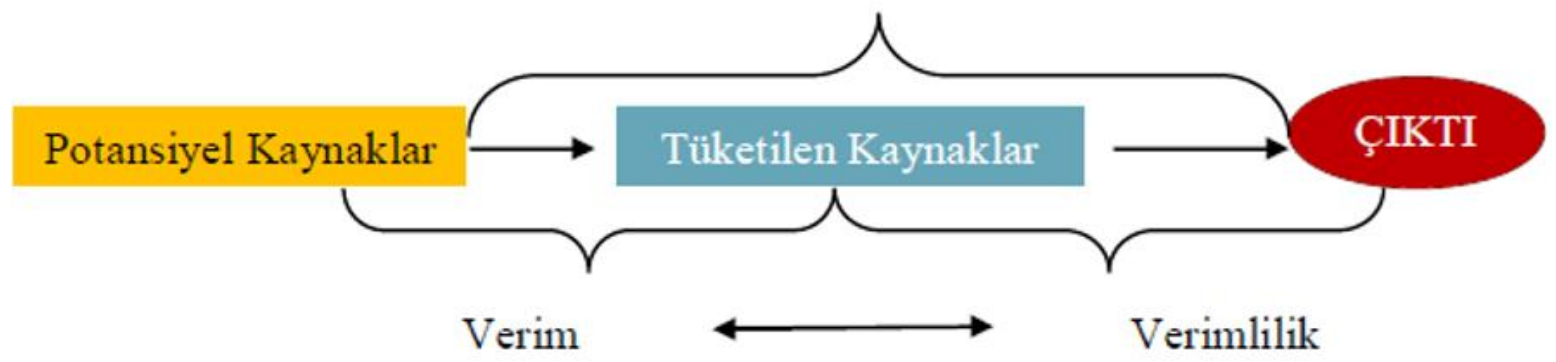

Şekil 1. Verim ile verimlilik arasındaki ilişki (Erpolat, 2011)

Figure 1. Relationship between efficiency and productivity (Erpolat, 2011)

Organizasyonların yönetim açısından karşılaştıkları sorunlardan biri de benzer girdileri kullanarak benzer çıktılar üreten işletmelerin karşılaştırılması ve etkinlik durumlarının incelenmesidir. Çeşitli sektörlerdeki işletmelerin (banka, üniversite, otel, kamu kurumu vb.) etkinliklerinin ölçülmesi ve karşılaştırılarak faaliyetlerine yön verilmesi hem işletmeler adına hem de ülke ekonomisi açısından önem taşımaktadır (Ulucan, 2004).

Doğru bir ölçüm olmadan işletmelerin benzerleri içerisinde hangi konumda bulunduklarını, üstün ve zayıf yönlerini, neye ve kime göre daha iyi olduklarını belirlemeleri mümkün değildir (Yeşilyurt, 2009).

Performansın ölçümü konusunda farklı yöntemler geçmişten günümüze uygulanmaktadır. Geleneksel ve yeni yaklaşımlar olarak sinıflanan ölçme yöntemleri, geleneksel yaklaşımların büyük bir kısmının oransal yaklaşım üzerinden ilerlemesi ve oransal yaklaşımın da fazla girdili ve fazla çıktılı performans değerlendirmelerinde zorlanmas üzerine, yeni yaklaşımların benimsenmesine yol açmıştır. Bu yeni yaklaşımlar ise kendi içerisinde parametrik ve parametrik olmayan ölçüm yöntemleri olarak sinıflanmaktadır. Parametrik yöntemler birden fazla girdinin tek bir çıktı ile ilişkisini incelediği için bu çalışmada çok girdili ve çok çıktılı verilerin incelenmesinde tercih edilen parametrik olmayan yöntemler uygulanmıştır.

Parametrik olmayan uygulamalar içinde en yaygın olarak kullanılan yaklaşım olan veri zarflama analizinde ise en uygun gözlemlerden oluşan etkinlik sınırı belirlenmektedir. Sonrasında ise tüm birimlerin bu belirlenen etkinlik sınırına olan uzaklıkları analiz edilerek elde edilen sonuçlar yorumlanmaktadır. Elde edilen etkinlik değerleri 1 ise bu birimler etkin olarak ifade edilmekte olup, etkinlik değeri 1'den küçük olanlar ise etkin olmayanlar şeklinde tanımlanmıştır. Etkin olmayan bir etkinlik değeri ile etkin bir birimin değeri (1) arasındaki fark bizlere sözü edilen fark oranında daha az girdi ile elde edilen çıktının yine elde edilmesinin mümkün olacağını söylemektedir (Bektaş, 2007).

Çalışmanın amacı, Samsun Ondokuz Mayıs Üniversitesi Eğitim ve Araştırma Hastanesi bünyesinde faaliyet gösteren anabilim dallarının etkinlik değerlerinin veri zarflama analizi modelleri ile belirlenmesidir.

Bu çalışma dört ana başlıktan oluşmaktadır: İkinci bölümde çalışmada kullanılan yöntem olan veri zarflama analizi ve Banker Charnes Cooper (BCC) ve Charnes Cooper Rhodes (CCR) modelleri teorik olarak kısaca tanıtılmıştır. Üçüncü bölümde BCC 
girdi yönlü, BCC çıktı yönlü, CCR girdi yönlü ve CCR çıtı yönlü modelleri için uygulama sonucunda elde edilen bulgulara yer verilmiştir. Tartışma ve sonuç ise dördüncü bölümde yer almaktadır.

\section{Materyal ve metot}

\section{Material and method}

\subsection{Veri zarflama analizi}

\subsection{Data envelopment analysis}

Veri zarflama analizi (VZA), doğrusal programlama teorisinin ilkelerine dayanan karar verme birimlerinin verimliliğini tahmin etmek için tasarlanmış parametrik olmayan bir yöntemdir (Norman \& Stoker, 1991). 1951 yllinda ilk kez etkinlik kavramını ortaya atan Koopmans (1951)'ın çalışmasından yola çıkan Debreu (1951) ve Farrell (1957) çalışmalarında çok girdili işletmelerin etkinlik ölçümlerini yapmışlardır. Farrell (1957), birden fazla girdisi ve tek çıktısı olan firmaların etkinliklerini analiz etmiștir. Sonrasında ise Carnegie Mellon Üniversitesine bağlı, danışmanlığını William W. Cooper'ın yaptığı Edwardo Rhodes "Şehir ve Kamu" başlıklı doktora tezi ile Amerika Birleşik Devletlerinde "Program Follow Through" 'a katılan ve katılmayan okulların performanslarını karşılaştırarak, eğitim programını değerlendirmeyi amaçlamış ve ilk VZA çalışmasına başlamıştır (Yaylalı vd,, 2007; Charnes vd., 1994). Bu çalışmada 70 tane okulun göreli teknik verimliliğini analiz etmek adına çoklu girdiler ve çıktılar kullanarak ve fiyatları göz ardı ederek tahmin etme arzusu VZA oransal denklemini doğurmuştur ki bu denklem sonrasında Charnes Cooper Rhodes (CCR) adı altında yaygın biçimde kullanılmaya devam etmektedir (Charnes vd., 1981; Kutlar \& Kartal, 2004).

1978 y1lında ise Charnes, Cooper ve Rhodes "Measuring The Efficiency of Decision Making Units" başlıklı makalelerini Europan Journal of Operations Research dergisinde yayımlatarak VZA'ni literatüre kazandırmışlardır. Onlar, VZA'ni ortaya koydukları mal ya da hizmet bakımından benzeri üretimler gerçekleştiren işletmelerin göreli etkinliklerinin analiz edilmesi için tasarlanmış parametrik olmayan bir etkinlik ölçütü şeklinde ifade etmişlerdir (Cook \& Seiford, 2009). Bu çalışmada Charnes, Cooper ve Rhodes ölçeğe göre sabit getiri durumunu varsaymaktadırlar (Charnes vd., 1978).

VZA'nin bir süre sabit getiri varsayımı ile etkinlik ölçümünde kullanılmasının ardından yapılan bazı çalışmalar ile ölçeğe göre getirinin sabit olmadığ 1 durumlarda ölçek ve teknik etkinliklerinin ayrı ayrı ölçülmesini sağlar hale gelen bir VZA yaratılmıştır.

1984 y1lında Banker, Charnes ve Cooper'nn ortak çalışmalarında teknik etkinlik ve ölçek etkinliğini belirlemek için ölçeğe göre değişken getiri durumu incelenmiştir. $\mathrm{Bu}$ durum da literatüre Banker Charnes Cooper (BCC) modeli olarak geçmiştir (Banker vd., 1984).

BCC modelinin CCR modeline göre kazanımları ise CCR modelinin ölçeğe göre sabit getiri hipotezini esnekleştirerek, çoklu girdi ve çoklu çıktı durumlarında işletmelerin performansını ölçeğe göre artan, azalan veya sabit getiri varsayımı ile analiz edilmesine izin vermesidir (Yolalan, 1993).

VZA'nde kullanılan CCR ve BCC modellerinin her biri girdi ve çıtı yönelimli olarak uygulanabilmektedir. Bu dört farklı model Şekil 2 'de gösterildiği gibidir. Bu modeller, uygulandığı çalışmalarda tutarlı analizler yapılmasına imkan sağlamaktadır. $\mathrm{Bu}$ sayede farklı uygulama alanlarında kullanılabilmektedir (İleri, 1997).

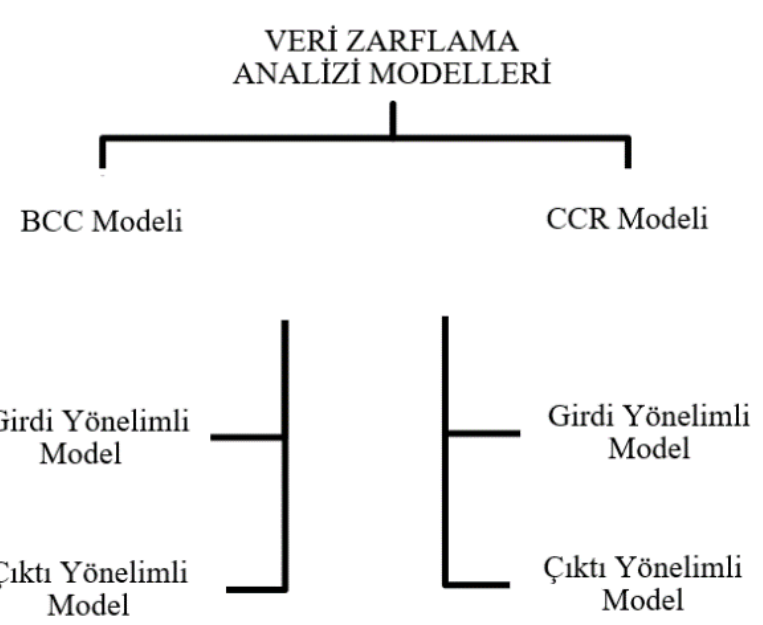

Şekil 2. VZA modelleri (Atan, 2005).

Figure 2. DEA models (Atan, 2005).

VZA, üretim yaptıkları ürünler açısından veya hizmetleri açısından birbirine benzeyen kurum, kuruluş ya da işletmelerin göreli etkinliğinin ölçülmesi amacıyla elde var olan kaynakların nasıl etkin bir biçimde kullanılacağının belirlenmesine yardımcı olur (Yolalan, 1993).

VZA'nin güçlü yönleri şu şekilde sıralanabilir; Parametrik yöntemlerde olduğu gibi girdiler ile çıktılar arasında fonksiyonel bir bağıntıya ihtiyaç duymaz (Depren, 2008). Girdi birimleri ile çıktı birimlerinin aynı tür olması zorunlu değildir. $\mathrm{Bu}$ 
sayede birimleri aynı olmayan varsayımlar için bir k1sit yoktur (Atan, 2005). VZA elde olan veri setini değerlendirerek etkinliği analiz eder. Evrensel bir yargıda bulunmaz. VZA'nin diğer istatistiksel yöntemlerden üstünlüğü en uygun veri setini bulma gibi bir gayesi olmamasıdır (Dilts vd, 2015).

VZA etkin olmayan karar verme birimlerinin kendilerini güncelleyerek etkin hale gelmeleri adına seçenekler sunar. Karar verici bu seçeneklerden yararlanarak en uygun seçimi yapabilir (Kecek, 2010). Yöneticilerin alakalı tüm girdi ve çıktıları tanımlayarak VZA yöntemini kullanması üretim sürecine daha hakim olmalarını sağlar (Başkaya \& Avc1, 2011). Sadece karar verme birimlerinin değil, zaman dilimlerinin de analizinin yapılmasına imkan tanır (Aydagün, 2003).

VZA'da çok önemli bir kavram olan etkin sınır kavramı, analizi yapılan karar verme birimlerinden yola çııılarak, göreceli olarak etkin birimler tarafindan meydana getirilen ve bu sınırın dışında kalan, solda ve altta hiçbir üretim faaliyetinin var olmadığı, parçalı, doğrusal bir set olarak ifade edilmektedir (Bal, 2010). Durumun daha iyi kavranması adına, aşağıdaki grafikte iki girdisi ve bir çıktısı olan iki boyutlu bir etkin sınır verilmiştir.

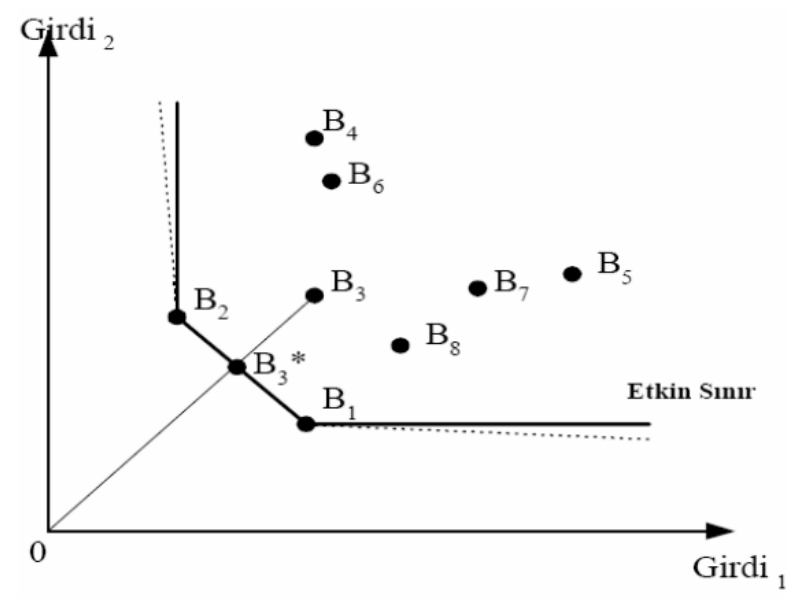

Şekil 3. İki boyutlu bir etkin sınır eğrisi ve VZA (Güran \& Cingi, 2002).

Figure 3. A two-dimensional effective boundary curve and DEA (Güran \& Cingi, 2002).

Şekil 3 incelendiğinde, her bir karar verme birimine ait çıktılar için kullanılan toplam girdilerin oranları verilmiştir. Belirlenen etkin sınır kavramı baz alındığında, B1 ve B2 karar verme birimlerinin en az sayıda girdi kullanarak çıtı üretmeyi başarmış oldukları görülmektedir. $\mathrm{Bu}$ sebeple etkin karar verme birimi olarak adlandırılabilirler.
Karar verme birimleri ile etkin sınır çizgisi arasındaki mesafe azaldıkça etkin hale gelme durumu ortaya çıkmakla beraber, tam çizginin üzerinde yer aldıklarında ise etkin bir karar verme birimi olmaktadırlar. $\mathrm{Bu}$ sayede etkin ve etkin olmayan karar verme birimleri net bir şekilde ayrılmaktadır. $\mathrm{Bu}$ göreli etkinliğin ölçülmesi durumu VZA'nin en önemli özelliklerinden biridir. Bir veri setinde yer alan karar verme birimlerinin etkinlik değerleri analiz edilirken, sette yer alan en etkin karar verme birimine göre değerlendirme yapilır. Bu duruma göre B3, B4, B5, B6, B7, B8 karar verme birimleri, $\mathrm{B} 1$ ve $\mathrm{B} 2$ 'ye göre karşılaştıııldıklarında etkin birimler değillerdir. Bu karar verme birimleri referans olarak B1 ve B2 karar verme birimlerini alırlarsa etkin hale gelebilmeleri mümkündür. Örneğin, B3 karar verme biriminin etkin hale gelebileceği nokta B3* ile ifade edilmiştir. Yani girdilerini istenilen şekilde düzenleyerek çıktıyı elde ettiğinde grafikte $\mathrm{B} 3$ * konumunda yer alacaktır. Bu durumda B1-B2 doğrusu üzerinde etkin hale gelebilecek her karar verme birimi için bir nokta olduğu varsayılmaktadır. $\mathrm{Bu}$ da etkin sınırın var olan gözlemleri bir zarf gibi sarmas1 anlamına gelmektedir. $\mathrm{Bu}$ sayede VZA olarak isimlendirilmektedir (Güran \& Cingi, 2002).

\subsection{Modeller \\ 2.2. Models}

Çalışmada kullanılan BCC girdi yönlü, BCC çıktı yönlü, CCR girdi yönlü ve CCR çıktı yönlü modellerden aşağıda kısaca bahsedilmiştir. $\mathrm{Bu}$ modeller için $n$ : karar verme birimi sayısı; $s$ : çıktı say1s1; $m$ : girdi sayıs1; $u_{\mathrm{r}}$ : o. karar verme birimi tarafından $r$. çıktıya verilen ağırlık değeri; $v_{i}:$ o. karar verme birimi tarafindan $i$. girdiye verilen ağırlı değeri; $x_{j o}$ : o. karar verme biriminin kullanıldığ 1 . girdi miktarı; $y_{r o}$ : o. karar verme biriminin kullanıldığı $r$. çıktı miktarı; $x_{i j}$ : j. karar verme biriminin kullanıldığ $i$. girdi miktarı; $y_{r j}$ : j. karar verme biriminin elde ettiği $r$. çıktı miktarını göstermektedir (Sathye, 2003).

\subsubsection{BCC girdi yönlü model \\ 2.2.1. BCC input oriented model}

Girdi yönlü BCC modeli çıktı değerlerini sabitlemek şartıyla girdi miktarının ne kadar azaltılabileceği konusunda hedefler sunan model olarak tanımlanabilir. Girdi yönlü BCC modelinin matematiksel ifadesi;

$E_{O}=\max \frac{\sum_{r=1}^{s} u_{r} y_{r o}-u_{o}}{\sum_{i=1}^{m} v_{i} x_{i o}}$ 


$$
\begin{array}{ll}
\text { Kisitlar, } & \frac{\sum_{r=1}^{S} u_{r} y_{r j}-u_{o}}{\sum_{i=1}^{m} v_{i} x_{i j}} \leq 1 \quad j=1,2, \ldots n \\
v_{i}, u_{r} \geq \varepsilon \quad & r=1,2, \ldots s \quad i=1,2, \ldots m
\end{array}
$$

şeklindedir. Burada, $u_{o}$ : o. karar verme birimine ait serbest işaretli değişkenini gösterir (Yun vd, 2004).

\subsubsection{BCC çıktı yönlü model}

\subsubsection{BCC output oriented model}

Çıktıya yönelik modeldeki temel amaç eldeki girdi seviyesini aşmadan çıktı miktarını maksimum hale getirmektir. Çıktı yönlü BCC modelinin matematiksel ifadesi;

$E_{O}=\min \frac{\sum_{i=1}^{m} v_{i} x_{i o}-v_{O}}{\sum_{r=1}^{s} u_{r} y_{r o}}$

Kisitlar, $\quad \frac{\sum_{i=1}^{m} v_{i} x_{i j}-v_{o}}{\sum_{r=1}^{s} u_{r} y_{r j}} \geq 1 \quad j=1,2, \ldots n$

$v_{i}, u_{r} \geq \varepsilon \quad r=1,2, \ldots s \quad i=1,2, \ldots m$

şeklindedir. Burada $v_{o}$ : o. karar verme birimine ait serbest işaretli değişkeni gösterir (Chen \& Ali, 2002).

\subsubsection{CCR girdi yönlü model}

2.2.3. CCR input oriented model

Var olan çıktı miktarında bir oynama yapmadan, eldeki çıktı miktarını elde etmek adına, girdilerin ne kadar azaltılması gerektiğini ifade eden modeldir (Matthews \& İsmail, 2006). Modelin matematiksel yapısı;

$E_{O}=\max \frac{\sum_{r=1}^{S} u_{r} y_{r o}}{\sum_{i=1}^{m} v_{i} x_{i o}}$

Kisitlar, $\quad \frac{\sum_{r=1}^{s} u_{r} y_{r j}}{\sum_{i=1}^{m} v_{i} x_{i j}} \leq 1 \quad j=1,2, \ldots n$

$v_{i}, u_{r} \geq 0 \quad r=1,2, \ldots s \quad i=1,2, \ldots m$

şeklindedir (Chen \& Ali, 2002).

\subsubsection{CCR çıktı yönlü model}

2.2.4. CCR output oriented model

Var olan girdi miktarında bir oynama yapmadan, eldeki girdiler ile karar verme birimini etkin hale getirmek için çıktıların hangi oranda arttırılması gerektiğini ifade eden modeldir (Matthews \& İsmail, 2006). Girdi yönlü VZA'dan fark1 ise ağırlıklandırılmış girdiyle, ağırlıklandırılmış çıktının oranını minimize etmeye çalışmasıdır. Modelin matematiksel yapısı;

$$
\begin{array}{lll}
E_{O}=\min \frac{\sum_{i=1}^{m} v_{i} x_{i o}}{\sum_{r=1}^{s} u_{r} y_{r o}} & \\
\text { Kisitlar, } & \frac{\sum_{i=1}^{m} v_{i} x_{i j}}{\sum_{r=1}^{s} u_{r} y_{r j}} \geq 1 & j=1,2, \ldots n \\
v_{i}, u_{r} \geq \varepsilon & r=1,2, \ldots s & i=1,2, \ldots m
\end{array}
$$

şeklindedir (Yolalan, 1993).

\section{Bulgular}

3. Results

Bu çalışmada kullanılan veriler bir Eğitim ve Araştırma Hastanesinden elde edilmiştir. Hastanede aktif çalışan ve yatan hasta servisleri bulunan anabilim dallarının tercih edilmesine önem verilmiştir. Çalışmada analizler 2018 yılında Ocak-Kasım ayları arasındaki 11 aylık hastane kayıtları kullanılarak yapılmıştır. Verilerin etkinlik değerlerinin ölçülmesi ve diğer analizler için MaxDEA 6 paket programından yararlanılmıştır.

Mevcut verilerin etkinlik seviyelerini en uygun biçimde yorumlamak ve değerlenmek için analizlerde VZA yönteminin dört farklı modeli uygulanmıştır ve sonuçlar tablolar halinde ifade edilmiştir. Analiz değerleri; tüm anabilim dallarının etkinlik değerlerini, etkin hale gelebilmesi için referans olarak görmesi gereken birimleri ve kullanılan girdi-çıktıların kaç tanesinde ne seviyede güncellemeler yapilırsa ne kadar etkin hale gelebileceği şeklinde bilgi ifadelerini kapsamaktadır. Etkinlik değerlendirmesinde kullanılacak değişkenler Tablo 2 'de ve BCC girdi yönlü model uygulanarak elde edilen sonuçlar ise Tablo 3 'te ifade edilmiştir.

Tablo 2. Çalışmada kullanılan değişkenler

Table 2. Variables used in the study

\begin{tabular}{lll}
\hline Girdiler & Çıktılar (Yıllık) \\
\hline 1) & Öğretim Üyesi ve Öğretim Görevlisi Sayıs1 & 1) Günlük Ayakta Muayene Sayısı \\
2) & Asistan Doktor Sayısı & 2) Yatan Günlük Hasta Sayısı \\
3) & Hasta Bakıcı Sayısı & 3) Ameliyat Sayısı \\
4) & Hemşire Sayıs1 & \\
\hline
\end{tabular}


Tablo 3. Anabilim dalları için BCC girdi yönlü model sonuçları

Table 3. BCC input-oriented model results for departments

\begin{tabular}{|c|c|c|c|c|}
\hline & Anabilim dalları & $\begin{array}{l}\text { Etkinlik } \\
\text { skoru }\end{array}$ & $\begin{array}{l}\text { Referans kümesindeki anabilim } \\
\text { dalları }\end{array}$ & $\begin{array}{c}\text { Referans } \\
\text { alinma } \\
\text { frekansı }\end{array}$ \\
\hline 1) & Acil ve İlkyardım & 1 & $\mathbf{1}(1.00)$ & 7 \\
\hline 2) & Anesteziyoloji & 0.574729 & 3(0.92); 4(0.08) & 0 \\
\hline 3) & Beyin Cerrahi & 1 & $\mathbf{3}(1.00)$ & 6 \\
\hline 4) & Çocuk Cerrahisi ve Ürolojisi & 1 & $\mathbf{4}(1.00)$ & 6 \\
\hline 5) & Çocuk Sağlığı ve Hastalıkları & 0.968837 & $\mathbf{1}(0.24) ; \mathbf{1 3}(0.76)$ & 0 \\
\hline 6) & Dermatoloji & 1 & $\mathbf{6}(1.00)$ & 8 \\
\hline 7) & Enfeksiyon Hastalıkları & 0.5 & $\mathbf{4}(0.31) ; \mathbf{6}(0.35) ; \mathbf{1 1}(0.14) ; \mathbf{2 6}(0.20)$ & 0 \\
\hline 8) & Fizik Tedavi ve Rehabilitasyon & 0.744492 & $\mathbf{1}(0.03) ; \mathbf{1 2}(0.33) ; \mathbf{2 6}(0.66)$ & 0 \\
\hline 9) & Genel Cerrahi & 0.5312 & $\begin{array}{lcc}\mathbf{3}(0.20) ; & \mathbf{4}(0.21) ; & \mathbf{6}(0.08) \\
\mathbf{1 2}(0.05) ; \mathbf{1 3}(0.03) ; \mathbf{2 1}(0.33) ; & \mathbf{2 7}(0.10)\end{array}$ & 0 \\
\hline 10) & Göğüs Cerrahi & 0.8 & $\mathbf{1 1}(0.32) ; \mathbf{2 1}(0.18) ; \mathbf{2 6}(0.50)$ & 0 \\
\hline 11) & Göğüs Hastalıkları & 1 & $\mathbf{6}(0.66) ; \mathbf{2 6}(0.34)$ & 2 \\
\hline 12) & Göz Hastalıkları & 1 & 12(1.00) & 4 \\
\hline 13) & İç Hastalıkları & 1 & $\mathbf{1 3}(1.00)$ & 4 \\
\hline 14) & Kadın Hastalıkları ve Doğum & 0.907163 & $\begin{array}{l}\mathbf{1}(0.01) ; \quad \mathbf{3}(0.17) \\
\mathbf{6}(0.06) ; \mathbf{1 3}(0.12) ; \mathbf{2 1}(0.44)\end{array}$ & 0 \\
\hline 15) & Kalp Damar Cerrahi & 0.8 & $\mathbf{4}(0.58) ; 21(0.19) ; \mathbf{2 6}(0.23)$ & 0 \\
\hline 16) & Kardiyoloji & 0.700961 & $\mathbf{1}(0.12) ; \mathbf{3}(0.41) ; \mathbf{6}(0.46) ; \mathbf{1 3}(0.005)$ & 0 \\
\hline 17) & Kulak Burun Boğaz & 0.900369 & $\begin{array}{l}\mathbf{1}(0.05) ; \mathbf{3}(0.03) ; \quad \mathbf{1 2}(0.20) ; \mathbf{2 1}(0.27) ; \\
\mathbf{2 6}(0.45)\end{array}$ & 0 \\
\hline 18) & Nöroloji & 0.432695 & $\begin{array}{l}\mathbf{1}(0.16) ; \mathbf{3}(0.12) ; \quad \mathbf{4}(0.15) ; \quad \mathbf{6}(0.22) ; \\
\mathbf{2 6}(0.35)\end{array}$ & 0 \\
\hline 19) & Nükleer Tip & 1 & 19(1.00) & 0 \\
\hline 20) & Ortopedi ve Travmatoloji & 0.625655 & $\begin{array}{l}\mathbf{1}(0.05) ; \mathbf{6}(0.26) ; \quad \mathbf{1 2}(0.05) ; \mathbf{2 1}(0.32) ; \\
\mathbf{2 6}(0.32)\end{array}$ & 0 \\
\hline 21) & $\begin{array}{l}\text { Plastik Rekonstrüktif ve Estetik } \\
\text { Cerrahi }\end{array}$ & 1 & $\mathbf{2 1}(1.00)$ & 6 \\
\hline 22) & Psikiyatri & 0.8 & $\mathbf{6}(0.63) ; \mathbf{2 6}(0.37)$ & 0 \\
\hline 23) & Radyasyon Onkoloji & 1 & $\mathbf{2 3}(1.00)$ & 0 \\
\hline 24) & Radyoloji & 1 & $\mathbf{2 4}(1.00)$ & 0 \\
\hline 25) & Tibbi Biyokimya & 0.666667 & $\mathbf{2 6}(1.00)$ & 0 \\
\hline 26) & Tibbi Genetik/Pediatri & 1 & $\mathbf{2 6}(1.00)$ & 10 \\
\hline 27) & Üroloji & 1 & $\mathbf{2 7}(1.00)$ & 1 \\
\hline
\end{tabular}

Tablo 3'e göre analize dahil ettiğimiz 27 anabilim dalından 13'ü BCC girdi yönlü VZA modeline göre etkin durumdadır. Bahsi geçen karar verme birimleri ise Acil ve İlkyardım, Beyin Cerrahi, Çocuk Cerrahisi ve Ürolojisi, Dermatoloji, Göğüs Hastalıkları, Göz Hastalıkları, İç Hastalıkları, Nükleer Tip, Plastik Rekonstrüktif ve Estetik Cerrahi, Radyasyon Onkoloji, Radyoloji, Tibbi Genetik/Pediatri, Üroloji ana bilim dalı (ABD)'dır.

Acil ve İlkyardım ABD, etkin durumda bulunmayan ABD'ları aracılığıyla 7 defa referans gösterilmiştir. Benzer şekilde Beyin Cerrahi 6 defa, Çocuk Cerrahisi ve Ürolojisi 6 defa, Dermatoloji 8 defa, Göğüs Hastalıkları 2 defa, Göz Hastalıkları 4 defa, İç Hastalıkları 4 defa, Plastik Rekonstrüktif ve Estetik Cerrahi 6 defa, Tıbbi Genetik/Pediatri etkin durumda bulunmayan ABD'ları tarafindan 10 defa referans gösterilmiştir. Ayrıca etkin durumdaki ABD'larından Göz Hastalıkları, etkin olmayan Fizik Tedavi ve Rehabilitasyon, Genel Cerrahi, Kulak Burun Boğaz ve Ortopedi ve Travmatoloji tarafından referans olarak alınmıştır. Ancak, Nükleer Tıp etkin bir ABD olmasına rağmen hiçbir $\mathrm{ABD}$ aracılı̆̆ıyla referans olarak gösterilmemiştir.

Tablo 3'e göre, etkin olmayan ABD'larının hangi etkin karar verme birimleri referans almaları gerektiği söylenebilir. Örneğin, Anesteziyoloji ABD'nın etkinlik skorunun 0,574729 değeri ile etkin olmadığ 1 görülmektedir. Etkin hale gelmesi için Beyin Cerrahisi ve Çocuk Cerrahisi ve Ürolojisi ABD'larını referans alması 
gerekmektedir. Etkinlik değerini arttırabilmek için \%92 oranında Beyin Cerrahi, \%8 oranında ise Çocuk Cerrahisi ve Ürolojisi ABD'nı örnek alarak verilerini güncellemesi gerekmektedir. Bu sayede etkin bir anabilim dalı haline gelebilir.

Analiz sonucu elde edilen Girdi-Çıktı artık değerleri dikkate alınırsa, Psikiyatri ABD'nın etkinlik skoru $0,8^{\prime}$ dir ve bu skor ile etkin durumda değildir. Etkin bir ABD haline gelebilmek adına 1. girdi olan Öğretim Üyesi ve Öğretim Görevlisi Sayısını \%20 oranında düşürmeli, 2.girdi olan
Asistan Dr. Sayısını \%75,5 oranında düşürmeli, 3.girdi olan Hasta Bakıcı Sayısını \% 52,2 oranında düşürmeli ve 4.girdi olan Hemşire Sayısı Sayısını ise $\% 76,1$ oranında düşürmelidir. Bunlara ek olarak 2.çıktı olan Yatan Günlük Hasta Sayısını ise $\% 285,7$ oranında sayısal olarak yukarı çekebilirse etkin bir anabilim dalına dönüşecektir.

BCC çıktı yönlü model uygulanarak elde edilen anabilim dallarına ait sonuçlar Tablo 4'te verilmiștir.

Tablo 4. Anabilim dalları için BCC çıktı yönlü model sonuçları

Table 4. BCC output oriented model results for departments

\begin{tabular}{|c|c|c|c|c|}
\hline & Anabilim dalları & $\begin{array}{l}\text { Etkinlik } \\
\text { skoru }\end{array}$ & $\begin{array}{l}\text { Referans kümesindeki } \\
\text { anabilim dalları }\end{array}$ & $\begin{array}{l}\text { Referans } \\
\text { alınma } \\
\text { frekansı }\end{array}$ \\
\hline 1) & Acil ve İlkyardım & 1 & $\mathbf{1}(1.00)$ & 9 \\
\hline 2) & Anesteziyoloji & 0.941464 & $3(1.00)$ & 0 \\
\hline 3) & Beyin Cerrahi & 1 & $3(1.00))$ & 9 \\
\hline 4) & Cocuk Cerrahisi ve Üroloiisi & 1 & $4(1.00)$ & 4 \\
\hline 5) & Cocuk Sağlığ 1 ve Hastalıkları & 0.985962 & $\mathbf{1}(0.21) ; \mathbf{1 3}(0.79)$ & 0 \\
\hline 6) & Dermatoloji & 1 & $6(1.00)$ & 4 \\
\hline 7) & Enfeksiyon Hastalıkları & 0.436628 & $\begin{array}{l}\mathbf{3}(0.42) ; \mathbf{4}(0.07) ; \mathbf{6}(0.26) ; \mathbf{1 2}(0.23) \\
\mathbf{1 3}(0.02)\end{array}$ & 0 \\
\hline 8) & Fizik Tedavi ve Rehabilitasyon & 0.794862 & $\mathbf{1 2}(0.67) ; \mathbf{2 6}(0.33)$ & 0 \\
\hline 9) & Genel Cerrahi & 0.681916 & $\mathbf{1}(0.05) ; \mathbf{3}(0.14) ; \mathbf{1 3}(0.08) ; \mathbf{2 1}(0.73)$ & 0 \\
\hline 10) & Göğüs Cerrahi & 0.340602 & $\begin{array}{l}\text { 4(0.07); 6(0.34); 12(0.03); 21(0.42); } \\
\text { 27(0.14) }\end{array}$ & 0 \\
\hline 11) & Göğüs Hastalıkları & 0.773476 & $\mathbf{6}(1.00)$ & 0 \\
\hline 12) & Göz Hastalıkları & 1 & $12(1.00)$ & 7 \\
\hline 13) & İç Hastalıkları & 1 & $\mathbf{1 3}(1.00)$ & 5 \\
\hline 14) & Kadın Hastalıkları ve Doğum & 0.913257 & $\begin{array}{l}\mathbf{1}(0.002) ; \mathbf{3}(0.25) ; 4(0.07) ; \mathbf{6}(0.04) ; \\
\mathbf{1 3}(0.14) ; \mathbf{2 1}(0.50)\end{array}$ & 0 \\
\hline 15) & Kalp Damar Cerrahi & 0.720569 & $\mathbf{1}(0.02) ; \mathbf{3}(0.20) ; \mathbf{4}(0.51) ; \mathbf{2 1}(0.28)$ & 0 \\
\hline 16) & Kardiyoloji & 0.732932 & $\mathbf{1}(0.22) ; \mathbf{3}(0.73) ; \mathbf{1 3}(0.05)$ & 0 \\
\hline 17) & Kulak Burun Boğaz & 0.927803 & $\begin{array}{l}\mathbf{1}(0.05) ; \mathbf{3}(0.06) ; \mathbf{1 2}(0.28) ; \mathbf{2 1}(0.25) \\
\mathbf{2 6}(0.36)\end{array}$ & 0 \\
\hline 18) & Nöroloji & 0.497488 & $\mathbf{1}(0.50) ; \mathbf{3}(0.21) ; \mathbf{1 2}(0.07) ; \mathbf{2 6}(0.22)$ & 0 \\
\hline 19) & Nükleer Tıp & 1 & $\mathbf{1 9}(1.00)$ & 0 \\
\hline 20) & Ortopedi ve Travmatoloji & 0.669595 & $\begin{array}{l}\mathbf{1}(0.11) ; \mathbf{3}(0.15) ; \mathbf{1 2}(0.36) ; \mathbf{2 1}(0.30) \\
\mathbf{2 6}(0.08)\end{array}$ & 0 \\
\hline 21) & $\begin{array}{l}\text { Plastik Rekonstrüktif ve Estetik } \\
\text { Cerrahi }\end{array}$ & 1 & $\mathbf{2 1}(1.00)$ & 6 \\
\hline 22) & Psikiyatri & 0.578968 & $\mathbf{1}(0.21) ; \mathbf{1 2}(0.13) ; \mathbf{2 6}(0.66)$ & 0 \\
\hline 23) & Radyasyon Onkoloji & 1 & $\mathbf{2 3}(1.00)$ & 0 \\
\hline 24) & Radyoloji & 1 & $\mathbf{2 4}(1.00)$ & 0 \\
\hline 25) & Tibbi Biyokimya & 0.105106 & 26(1.00) & 0 \\
\hline 26) & Tibbi Genetik /Pediatri & 1 & $\mathbf{2 6}(1.00)$ & 6 \\
\hline 27) & Üroloji & 1 & $27(1.00)$ & 1 \\
\hline
\end{tabular}

Tablo 4'e göre analize dahil edilen 27 ABD'den 12'si BCC Çıktı yönlü VZA modeline göre etkin durumdadır. Bahsi geçen karar verme birimleri
Gögüs hastalıkları ABD hariç, BCC Girdi yönlü VZA modelindeki ile aynıdır.

Acil ve İlkyardım ABD, etkin durumda bulunmayan ABD'ları aracılı̆̆ıyla 9 defa referans 
gösterilmiştir. Benzer biçimde Beyin Cerrahi yine 9 defa, Çocuk Cerrahisi ve Ürolojisi 4 defa, Dermatoloji 4 defa, Göz Hastalıkları 7 defa, İç Hastalıkları 5 defa, Plastik Rekonstrüktif ve Estetik Cerrahi 6 defa, Tibbi Genetik/Pediatri 6 defa ve Üroloji etkin durumda bulunmayan ABD'lar1 aracılığıly 1 defa referans gösterilmiştir.

Ayrıca etkin durumda bulunan ABD'larından Trbbi Genetik/Pediatri, etkin olmayan Fizik Tedavi ve Rehabilitasyon, Kulak Burun Boğaz, Nöroloji, Ortopedi ve Travmatoloji, Psikiyatri ve Tibbi Biyokimya tarafından referans olarak alınmıştır. Ancak, Radyoloji etkin bir ABD olmasına rağmen hiçbir ABD aracıllğıyla referans olarak gösterilmemiştir.
Analiz sonucu elde edilen Girdi-Çıktı artık değerleri dikkate aldığında, Ortopedi ve Travmatoloji ABD'nın etkinlik skoru 0,669595'tir ve bu skor ile etkin olmadığı görülmektedir. Etkin hale gelebilmesi için 4.girdi olan Hemşire Sayısını $\% 23,3$ oranında düşürmeli, 1.çıktı olan Günlük Ayakta Muayene Sayısını \%49,3 oranında yükseltmeli, 2.çıktı olan Yatan Günlük Hasta Sayısın $\%$ 83,3 oranında yükseltmeli ve son olarak da 3.çıktı olan Ameliyat sayısını \% 49,3 oranında yükseltmelidir. İhtiyaç durulan bu değişimler sağlandığı durumda Ortopedi ve Travmatoloji ABD etkin ABD'ları arasına dahil olacaktır.

CCR girdi yönlü model uygulanarak elde edilen anabilim dallarına ait sonuçlar 5 'te verilmiştir (Güç \& Kasap, 2019; Güç, 2019).

Tablo 5. Anabilim dalları için CCR girdi yönlü model sonuçları

Table 5. CCR input oriented model results for departments

\begin{tabular}{|c|c|c|c|c|}
\hline & Anabilim dalları & $\begin{array}{l}\text { Etkinlik } \\
\text { skoru }\end{array}$ & $\begin{array}{l}\text { Referans kümesindeki } \\
\text { anabilim dalları }\end{array}$ & $\begin{array}{c}\text { Referans } \\
\text { alınma } \\
\text { frekansi }\end{array}$ \\
\hline 1) & Acil ve İlkyardım & 1 & $\mathbf{1}(1.00)$ & 10 \\
\hline 2) & Anesteziyoloji & 0.564879 & $3(0.94)$ & 0 \\
\hline 3) & Beyin Cerrahi & 1 & $3(1.00)$ & 5 \\
\hline 4) & Çocuk Cerrahisi ve Ürolojisi & 1 & $\mathbf{4}(1.00)$ & 6 \\
\hline 5) & Çocuk Sağlığı ve Hastalıkları & 0.712489 & $\mathbf{1}(1.63) ; \mathbf{1 3}(0.25)$ & 0 \\
\hline 6) & Dermatoloji & 1 & $6(1.00)$ & 9 \\
\hline 7) & Enfeksiyon Hastalıkları & 0.379292 & $\mathbf{4}(0.31) ; \mathbf{6}(0.41) ; \mathbf{1 2}(0.02)$ & 0 \\
\hline 8) & Fizik Tedavi ve Rehabilitasyon & 0.722409 & $\mathbf{1}(0.04) ; \mathbf{1 2}(0.23) ; \mathbf{2 6}(0.82)$ & 0 \\
\hline 9) & Genel Cerrahi & 0.492636 & $\mathbf{1}(0.008) ; \mathbf{4}(0.60) ; \mathbf{6}(0.49) ; \mathbf{2 1}(0.39)$ & 0 \\
\hline 10) & Göğüs Cerrahi & 0.331126 & $\begin{array}{lll}\mathbf{4}(0.04) ; & \mathbf{6}(0.19) ; & \mathbf{2 1}(0.17) ; \\
26(0.004) & \end{array}$ & 0 \\
\hline 11) & Göğüs Hastalıkları & 0.622501 & $\mathbf{1}(0.07) ; \mathbf{3}(0.02) ; \mathbf{6}(0.49)$ & 0 \\
\hline 12) & Göz Hastalıkları & 1 & $12(1.00)$ & 5 \\
\hline 13) & İç Hastalıkları & 1 & $\mathbf{1 3}(1.00)$ & 2 \\
\hline 14) & Kadın Hastalıkları ve Doğum & 0.887799 & $\mathbf{4}(0.37) ; \mathbf{6}(0.43) ; \mathbf{1 3}(0.09) ; \mathbf{2 1}(0.46)$ & 0 \\
\hline 15) & Kalp Damar Cerrahi & 0.701514 & $\mathbf{1}(0.001) ; \mathbf{3}(0.22) ; \mathbf{4}(0.12) ; \mathbf{2 1}(0.23)$ & 0 \\
\hline 16) & Kardiyoloji & 0.696393 & $\mathbf{1}(0.12) ; \mathbf{3}(0.40) ; \mathbf{6}(0.53)$ & 0 \\
\hline 17) & Kulak Burun Boğaz & 0.873336 & $\begin{array}{lll}\mathbf{1}(0.06) ; & \mathbf{1 2}(0.09) ; & \mathbf{2 1}(0.32) ; \\
\mathbf{2 6}(0.68) & & \end{array}$ & 0 \\
\hline 18) & Nöroloji & 0.428544 & $\mathbf{1}(0.14) ; \mathbf{3}(0.18) ; 6(0.28) ; \mathbf{2 6}(0.33)$ & 0 \\
\hline 19) & Nükleer Tıp & 1 & $\mathbf{1 9}(1.00)$ & 0 \\
\hline 20) & Ortopedi ve Travmatoloji & 0.624968 & $\begin{array}{l}\mathbf{1}(0.06) ; \mathbf{6}(0.25) ; \mathbf{1 2}(0.06) ; \mathbf{2 1}(0.32) ; \\
\mathbf{2 6}(0.31)\end{array}$ & 0 \\
\hline 21) & $\begin{array}{l}\text { Plastik Rekonstrüktif ve Estetik } \\
\text { Cerrahi }\end{array}$ & 1 & $\mathbf{2 1}(1.00)$ & 7 \\
\hline 22) & Psikiyatri & 0.558595 & $\mathbf{1}(0.13) ; \mathbf{2 6}(0.53)$ & 0 \\
\hline 23) & Radyasyon Onkoloji & 1 & $\mathbf{2 3}(1.00)$ & 1 \\
\hline 24) & Radyoloji & 1 & $\mathbf{2 4}(1.00)$ & 0 \\
\hline 25) & T1bbi Biyokimya & 0.07007 & $\mathbf{2 6}(0.11)$ & 0 \\
\hline 26) & Tibbi Genetik /Pediatri & 1 & $\mathbf{2 6}(1.00)$ & 6 \\
\hline 27) & Üroloji & 0.897368 & $\mathbf{4}(0.56) ; \mathbf{6}(1.02) ; \mathbf{1 2}(0.07) ; \mathbf{2 1}(0.46)$ & 0 \\
\hline
\end{tabular}


Tablo 5'e göre analize dahil ettiğimiz 27 ABD'nin 11'i CCR Girdi yönlü VZA modeline göre etkin durumdadır. Bahsi geçen karar verme birimleri Üroloji ABD hariç, BCC çıktı yünlü VZA modelindeki ile aynıdır. CCR girdi yönlü analiz detayları için bkz. (Güç \& Kasap, 2019).

CCR çıktı yönlü model uygulanarak elde edilen anabilim dallarına ait sonuçlar Tablo 6'da verilmiştir (Güç \& Kasap, 2019; Güç, 2019).

Tablo 6. Anabilim dalları için CCR çıktı yönlü model sonuçları

Table 6. CCR output-oriented model results for departments

\begin{tabular}{|c|c|c|c|c|c|}
\hline & Anabilim dalları & $\begin{array}{l}\text { Etkinlik } \\
\text { skoru }\end{array}$ & \multicolumn{2}{|c|}{$\begin{array}{l}\text { Referans kümesindeki } \\
\text { anabilim dalları }\end{array}$} & $\begin{array}{l}\text { Referans } \\
\text { alınma } \\
\text { frekansı }\end{array}$ \\
\hline 1) & Acil ve İlkyardım & 1 & \multicolumn{2}{|l|}{$\mathbf{1}(1.00)$} & 10 \\
\hline 2) & Anesteziyoloji & 0.564879 & \multicolumn{2}{|l|}{ 3(1.66) } & 0 \\
\hline 3) & Beyin Cerrahi & 1 & \multicolumn{2}{|l|}{$\mathbf{3}(1.00)$} & 5 \\
\hline 4) & Çocuk Cerrahisi ve Ürolojisi & 1 & \multicolumn{2}{|l|}{$4(1.00)$} & 6 \\
\hline 5) & Çocuk Sağlığı ve Hastalıkları & 0.712489 & \multicolumn{2}{|l|}{$\mathbf{1}(2.29) ; \mathbf{1 3}(0.36)$} & 0 \\
\hline 6) & Dermatoloji & 1 & \multicolumn{2}{|c|}{$\mathbf{6}(1.00)$} & 9 \\
\hline 7) & Enfeksiyon Hastalıkları & 0.379292 & \multicolumn{2}{|c|}{$\mathbf{4}(0.81) ; \mathbf{6}(1.08) ; \mathbf{1 2}(0.04)$} & 0 \\
\hline 8) & $\begin{array}{ll}\text { Fizik } & \text { Tedavi } \\
\text { Rehahilitasyon }\end{array}$ & 0.722409 & \multicolumn{2}{|c|}{$\mathbf{1}(0.06) ; \mathbf{1 2}(0.32) ; \mathbf{2 6}(1.13)$} & 0 \\
\hline 9) & Genel Cerrahi & 0.492636 & $\begin{array}{l}\mathbf{1}(0.02) ; \quad \mathbf{4}(1.20) \\
\mathbf{2 1}(0.79)\end{array}$ & $\mathbf{6}(0.99)$ & 0 \\
\hline 10) & Göğüs Cerrahi & 0.331126 & $\begin{array}{l}\mathbf{4}(0.13) ; \quad \mathbf{6}(0.58) \\
\mathbf{2 3}(0.01)\end{array}$ & $\mathbf{2 1}(0.52)$ & 0 \\
\hline 11) & Göğüs Hastalıkları & 0.622501 & $\mathbf{1}(0.11) ; \mathbf{3}(0.03) ; \mathbf{6}(0$. & & 0 \\
\hline 12) & Göz Hastalıkları & 1 & 12(1.00) & & 5 \\
\hline 13) & İç Hastalıkları & 1 & 13(1.00) & & 2 \\
\hline 14) & Kadın Hastalıkları ve Doğum & 0.887799 & $\begin{array}{l}\mathbf{4}(0.41) \\
\mathbf{2 1}(0.51)\end{array}$ & $\mathbf{1 3}(0.10)$ & 0 \\
\hline 15) & Kalp Damar Cerrahi & 0.701514 & $\begin{array}{l}\text { 1(0.002); } \mathbf{3}(0.33) ; \\
\mathbf{2 1}(0.33)\end{array}$ & $\mathbf{4}(0.18)$ & 0 \\
\hline 16) & Kardiyoloji & 0.696393 & $\mathbf{1}(0.17) ; \mathbf{3}(0.57) ; \mathbf{6}(0$. & & 0 \\
\hline 17) & Kulak Burun Boğaz & 0.873336 & $\begin{array}{l}\text { 1(0.07); 12(0.10); } \\
\mathbf{2 6}(0.79)\end{array}$ & $\mathbf{2 1}(0.37)$ & 0 \\
\hline 18) & Nöroloji & 0.428544 & $\begin{array}{l}\mathbf{1}(0.33) \\
\mathbf{6}(0.76)\end{array}$ & $6(0.65)$ & 0 \\
\hline 19) & Nükleer Tıp & 1 & $\mathbf{1 9}(1.00)$ & & 0 \\
\hline 20) & Ortopedi ve Travmatoloji & 0.624968 & $\begin{array}{l}\mathbf{1}(0.09) ; \quad \mathbf{6}(0.40) \\
\mathbf{2 1}(0.51) ; \mathbf{2 6}(0.50)\end{array}$ & 12(0.09); & 0 \\
\hline 21) & $\begin{array}{l}\text { Plastik Rekonstrüktif ve } \\
\text { Estetik Cerrahi }\end{array}$ & 1 & $\mathbf{2 1}(1.00)$ & & 7 \\
\hline 22) & Psikiyatri & 0.558595 & $\mathbf{1}(0.24) ; \mathbf{2 6}(0.96)$ & & 0 \\
\hline 23) & Radyasyon Onkoloji & 1 & $\mathbf{2 3}(1.00)$ & & 1 \\
\hline 24) & Radyoloji & 1 & $\mathbf{2 4}(1.00)$ & & 0 \\
\hline 25) & T1bbi Biyokimya & 0.07007 & $\mathbf{2 6}(1.50)$ & & 0 \\
\hline 26) & Tibbi Genetik /Pediatri & 1 & $\mathbf{2 6}(1.00)$ & & 6 \\
\hline 27) & Üroloji & 0.897368 & $\begin{array}{l}\mathbf{4}(0.63) \\
\mathbf{2 1}(0.51)\end{array}$ & 12(0.08); & 0 \\
\hline
\end{tabular}

Tablo 6'ya göre analize dahil ettiğimiz 27 ABD'den 11'i CCR Çıktı yönlü VZA modeline göre etkin durumdadır. Bahsi geçen karar verme birimleri CCR girdi yönlü VZA modeli ile aynıdır. CCR çıktı yönlü analiz detayları için bkz. (Güç \& Kasap, 2019). CCR ve BCC modellerinin tüm alt modelleri için analiz sonucunda elde edilen girdi- çıktı artık değerleri çalışmanın ekler bölümünde tablolar halinde verilmiştir.

Rastgele seçilmiş herhangi bir karar verme birimi için, *BCC: girdi yönlü $\mathrm{BCC}$ modeli etkinlik değeri ve *CCR: girdi yönlü CCR modeli etkinlik değeri olmak üzere ${ }^{*} \mathrm{BCC} \geq{ }^{*} \mathrm{CCR}$ kısitı tüm durumlarda gerçekleşir. Çünkü BCC modelindeki 
konveks üretim olanakları kümesi, CCR modelindeki üretim olanakları kümesinin bir alt kümesidir. Diğer bir deyişle CCR girdi yönlü model ile etkin bulunan rastgele seçilmiş bir karar verme birimi, mutlaka BCC girdi yönlü modelde de etkin olacaktır. Örneğin; Göğüs Hastalıkları ABD 'nın CCR girdi yönlü modele göre etkinlik değeri 0.622501 'dir. Yani etkin değildir. Ancak BCC Girdi yönlü model dikkate alındığında Gögüs Hastalıkları ABD' nın etkinlik değerinin 1 olduğunu görülmektedir. $\mathrm{Bu}$ da etkin bir karar verme birimi olduğunu göstermektedir ve yukarıda bahsedilen kısıtı sağlamaktadır.

\section{Tartışma ve sonuçlar}

\section{Discussion and conclusions}

Bir sektörün değerini veya önemini ortaya koyarken, sektörün üretiminin hangi bandında yer aldığına dikkat edilmelidir. Eğer birimler üretimleri sonucunda bir ürün ortaya koyuyorsa, o sektörün önemini ortaya koydukları ürünün ihtiyaçları gidermesi ya da hayatı kolaylaştırıcı etkileri açısından değerlendirmek mümkün olabilir. Ancak o sektöre bağlı birimler bir hizmet üretiyorsa, o sektörün değerini ürettikleri hizmet kalitesi ve önemi belirler. Bu açıdan bakıldığında ise sağllk sektörü tüm sektörlerin temelini oluşturan insan iş gücünün faaliyetlerini devam ettirebilmesine olanak sağladığ 1 için oldukça önemli bir konumdadır.

Sağlık ünitelerinin etkinliklerinin analizi ve bu analizler 1şığında tüm ünitelerden azami verimliliğe ulaşmak amacıyla VZA'nden faydalanılması gelişim ve değişim süreçlerinin en dikkat edilmesi gereken safhalarından bir tanesidir. VZA ile sektör himayesinde yer alan alt ünitelerin kendi içerisinde ve karşılıklı analizleri 1şı̆̆ında etkin halde bulunan karar verme birimlerinin belirlenmesi ve etkin durumda bulunmayan karar verme birimlerinin ise etkin duruma gelebilmesi için hangi oranla, hangi etkin birimi referans alması gerektiğini ve kendi koşullarını referans aldığ 1 bu etkin olan birime ya da birimlere göre tasarlamas1 gerektiği sonucunu veren VZA, uygulamada yaygın bir şekilde kullanılan elverişli bir modeldir.

$\mathrm{Bu}$ çalışmada incelenen dört modelde de 27 anabilim dalından 11 tanesi etkin haldedir. $\mathrm{Bu}$ anabilim dalları Acil ve İlkyardım, Beyin Cerrahi, Çocuk Cerrahisi ve Ürolojisi, Dermatoloji, Göz Hastalıkları, İç Hastalıkları, Nükleer Tıp, Plastik Rekonstrüktif ve Estetik Cerrahi, Radyasyon Onkoloji, Radyoloji ve Tibbi Genetik/Pediatri'dir. $\mathrm{Bu}$ sonuç, anabilim dallarının \% 40'ının etkin, \% 60 'ının ise etkin olmayan karar verme birimlerinden oluştuğunu göstermektedir. $\mathrm{Bu}$ bağlamda Eğitim ve Araştırma Hastanesi'nin toplam etkinliğini yükseltmek ve var olandan çok daha işlevsel bir kuruma dönüşmesi sağlamak için etkin durumda bulunmayan birimlerin veri setlerini, referans birimler 1şığında güncelleme çalışmalarının ilerleyen süre zarfında uygulaması gerekmektedir. Bununla birlikte kurumsal kalite ve verimliliğini koruyucu ve geliştirici hamleler yapmış olacaktır.

Günümüzde performans, etkinlik ve verimlilik gibi tanımlamalar belirli bir limite sahip olan kaynakların kullanımında her zaman kilit bir rol oynayacaktır. Var olan rekabet, kurumları (karar verme birimleri) kaynaklarını en etkin ve verimli bir şekilde kullanmaya zorlamaktadır (Oruç, 2009).

Araştırma doğrultusunda sonraki dönemlerde etkin olmayan karar verme birimlerinin gerekli referanslar doğrultusunda kendi anabilim dallarında değişime gidip-gitmedikleri veya etkinlik değerlerinde bir artış ya da azalış olup olmadığı tekrar araştırılabilir.

Araştırmada yer alan girdi ve çıktı kümeleri dikkate alınarak, araştırma farklı bir eğitim ve araştırma hastanesinde tekrarlanabilir ve anabilim dalları kıyaslanabilir. Bizim çalışmamızda etkin olan veya olmayan karar verme birimlerinin etkinlik değerleri ile yeni uygulamanın değerleri kıyaslanabilir. Farklı etkinlik skorlarının sebepleri sorgulanabilir, etkinlik skorlarını 1'e çekmek için her iki eğitim ve araştırma hastanesindeki referans kümeleri kıyaslanabilir.

\section{Teşekkür/Katkı Belirtme \\ Acknowledgement}

$\mathrm{Bu}$ çalışma yüksek lisans tez çalışmasından türetilmiştir ve herhangi bir proje tarafindan maddi olarak desteklenmemiştir. Makalenin inceleme ve değerlendirme aşamasında yapmış oldukları katkılardan dolayı editör ve hakemlere teşekkür ederiz.

\section{Yazar katkısı}

Author contribution

Yazarların çalışmaya eşit oranda katkısı bulunmaktadır. 


\section{Etik beyanı}

Declaration of ethical code

$\mathrm{Bu}$ makalenin yazarları, bu çalışmada kullanılan materyal ve yöntemlerin etik kurul izni gerektirmediğini beyan etmektedir.

\section{Çıkar çatışması beyanı \\ Conflicts of interest}

$\mathrm{Bu}$ makalenin yazarları, aralarında herhangi bir çıkar çatışması olmadığını beyan eder.

\section{Kaynaklar}

References

Aydagün, A. (2003). Veri zarflama analizi, [Y1lsonu Semineri, Milli Savunma Üniversitesi, Hava Harp Okulu, Havacılık ve Uzay Teknolojileri (HUTEN) Enstitüsü, Endüstri Mühendisliği Ana Bilim Dal1].

Atan, M. (2005). Üretim ve verimliliği artırma teknikleri. [Gazi Üniversitesi Ekonometri Bölümü Ders Notu] http://muratatan.info/notes/10.pdf.

Bakırer, A. (2016). 663 sayll KHK'nin devlet hastanelerinin verimliliklerine olan etkisinin veri zarflama analizi ile ölçümü [Yüksek Lisans Tezi, Cumhuriyet Üniversitesi, Sosyal Bilimler Enstitüsü].

Bal, V. (2010). Bilgi sistemlerinin sağllk işletmeleri performansina etkinlerinin veri zarflama analizi ile ölçümü: Türkiye'deki devlet hastanelerinde bir araştırma [Doktora Tezi, Isparta Süleyman Demirel Üniversitesi].

Banker, R.D., Charnes, A., \& Cooper, W.W. (1984). Some models for estimating technical and scale in efficiencies in data envelopment analysis. Management Science, 30(9), 1078-1092.

Barutçugil, İ. (2002). Performans yönetimi. Kariyer yayıncilik.

Baş, M., \& Artar, A. (1990). İşletmelerde verimlilik denetimi ölçme ve değerlendirme modelleri. MPM yayınları.

Başkaya, Z., \& Avcı, B. (2011). Veri zarflama analizi. (1. Bask1), Dora yayınları.

Bektaş, A. (2007). Ankara'daki özel liselerin etkinliğinin veri zarflama analizi ile ölçümü [Yüksek Lisans Tezi, Gazi Üniversitesi].

Charnes, A., Cooper, W.W., \& Rhodes, E. (1981). Evaluating program and managerial efficiency: an application of data envelopment analysis to program follow through. Management Science, 27(6), 668-697.
Charnes, A., Cooper, W.W., \& Rhodes, E. (1978). Measuring the efficiency of decision making units. European Journal of Operational Research, 2(6), 429-444.

Charnes, A., Cooper, W.W., Lewin, A.Y., \& Seiford, L.M. (Eds.) (1994). Data envelopment analysis: Theory, methodology and applications. Kluwer.

Chen, Y. \& Ali, A.I. (2002). Continuous optimization output-input ratio analysis and DEA frontier, European Journal of Operational Research. 12(142), 476-479.

Cook, W.D., \& Seiford, L.M. (2009). Data envelopment analysis (DEA) - Thirty years on. European Journal of Operational Research, 192(1), 1-17.

Debreu, G. (1951). The coefficient of resource utilization. Econometrica: Journal of the Econometric Society. 19(3), 273-292.

Depren, Ö. (2008). Veri zarflama analizi ve bir uygulama [Yüksek Lisans Tezi, Yıldız Teknik Üniversitesi Fen Bilimleri Enstitüsü].

Dilts, D.M., Zell, A., \& Orwoll, E. (2015). A novel approach to measuring efficiency of scientific research projects: data envelopment analysis. Clinical and Translational Science, 8(5), 495501.

Erdoğan, İ. (1991). İşletmelerde personel seçimi ve başarı değerleme teknikleri, Beta yayınları.

Erpolat, S. (2011). Veri zarflama analizi, Evrim yayınevi.

Farrell, M.J. (1957). The measurement of productive efficiency. Journal of the Royal Statistical Society: Series A (General), 120(3), 253-281.

Güç, F. (2019). Veri zarflama analizi ile performans değerlendirmesi ve sağllk alaninda bir uygulama. [Yayımlanmamış Yüksek Lisans Tezi, Ondokuz Mayıs Üniversitesi Fen Bilimleri Enstitüsü, İstatistik Anabilim Dalı].

Güç, F. \& Kasap, P. (2019). CCR modeli ile veri zarflama analizi ve bir uygulama, 2.Uluslararast İstatistik, Matematik ve Analitik Yöntemler Kongresi (ss.59-68), Güven Plus Grup A.Ş. Yayınları. E-ISBN: 978-605-7594-16-7.

Gülcü, A., Tutar, H., \& Yeşilyurt, C. (2004). Sağllk sektöründe veri zarflama analizi yöntemi ile göreceli verimlilik analizi. Seçkin Yayıncılık.

Güran, M.C., \& Cingi, S. (2002). Devletin ekonomik müdahalelerinin etkinliği. Akdeniz İ̈BF Dergisi, 3, 56-89.

İleri, İ. (1997). VZA kullanılarak bankacıllk sektöründe bir uygulama [Yayınlanmamış Yüksek Lisans 
Tezi, İstanbul Teknik Üniversitesi, Fen Bilimleri Enstitüsü].

Kecek, G. (2010). Veri zarflama analizi teori ve uygulama örneği (1. Bask1). Siyasal kitabevi.

Koopmans, T.C. (1951). An analysis of production as an efficient combination of activities Chapter III. T.C. Koopmans (Ed.) Activity analysis of production and allocation, Cowles Commission Monograph. New York: John Wiley and Sons.

Kutlar, A., \& Kartal M. (2004). Cumhuriyet üniversitesinin verimlilik analizi: fakülteler düzeyinde veri zarflama yöntemiyle bir uygulama. Kocaeli Üniversitesi Sosyal Bilimler Enstitüsü Dergisi 8(2), 49-79.

Matthews, K., \& Ismail, M. (2006). Efficiency and productivity growth of domestic and foreign commercial banks in Malaysia. Cardiff Economics Working Papers, 20(13)5 - 25.

Norman, M., \&_Stoker, B. (1991). Data envelopment analysis: The assessment of performance. Wiley.

Oruç, K.O., Güngör İ., \& Demiral, M.F. (2009). Üniversitelerin etkinlik ölçümünde bulanık veri zarflama analizi uygulaması. Selçuk Üniversitesi Sosyal Bilimler Enstitüsü Dergisi. 22, 279-294

Prokopenko, J. (Ed.). (1998). Management development: A guide for the profession. International Labour Organization.

Sathye, M. (2003). Efficiency of banks in a developing economy: The case of India. European Journal of Operational Research, 12(148), 662 - 671.
Timur, H. (2001). Personel başarı değerlendirmesi ve Türk adli yargı örneği. Amme İdaresi Dergisi $7(2), 129-137$.

Ulucan, A. (2004). Yöneylem araştırması işletmecilik uygulamalı bilgisayar destekli uygulama. Siyasal kitabevi.

Uyargil, C. (1994). İşletmelerde performans yönetim sistemi İstanbul. İstanbul Üniversitesi İşletme Fakültesi Yayını.

Yaylalı, M., Oktay, E., Akan, Y., \& Kaynak, S. (2007). Türkiye ve Avrupa Birliğine üye ülkelerin bilgi ekonomisi performanslarının veri zarflama analizi metoduyla karşılaştırılması. Marmara Üniversitesi İktisadi ve İari Bilimler Fakültesi Dergisi, 22(1), 1-25.

Yeşilyurt, C. (2009). Türkiye'deki iktisat bölümlerinin göreceli performanslarının veri zarflama analizi yöntemiyle ölçülmesi: KPSS 2007 verilerine dayalı bir uygulama. Atatürk Üniversitesi İktisadi ve İdari Bilimler Dergisi, 23(4), 135147.

Yolalan, R. (1993). İşletmeler arası göreli etkinlik ölçümü, MPM yayınları, No: 483.

Yun, Y.B., Nakayama, H., \& Tanıno, T. (2004). Continuous optimization a generalized model for data envelopment analysis. European Journal of Operational Research. 25(157), 89 - 91.

Yükçü, S., \& Atağan, G. (2009). Etkinlik, etkililik ve verimlilik kavramlarının yarattığı karışıklık, Atatürk Üniversitesi İktisadi ve İdari Bilimler Dergisi, 23(4), 1-12. 


\section{EKLER}

APPENDICES

Tablo I. Anabilim dalları için BCC girdi yönlü etkinlik değerleri ve girdi-çıtıların artık değerleri

Table I. BCC input-oriented efficiency values and residual values of input-outputs for departments

\begin{tabular}{|c|c|c|c|c|c|c|c|c|c|}
\hline & Anabilim dalları & $\begin{array}{c}\text { Etkinlik } \\
\text { skoru }\end{array}$ & $\begin{array}{c}\text { Öğretim } \\
\text { üyesi ve } \\
\text { öğretim } \\
\text { görevlisi } \\
\text { sayısındaki } \\
\text { fazlalık }\end{array}$ & $\begin{array}{l}\text { Asistan Dr. } \\
\text { sayısındaki } \\
\text { fazlalık }\end{array}$ & $\begin{array}{l}\text { Hasta bakıcı } \\
\text { sayısındaki } \\
\text { fazlalık }\end{array}$ & $\begin{array}{c}\text { Hemşire } \\
\text { sayısı } \\
\text { sayısındaki } \\
\text { fazlalık }\end{array}$ & $\begin{array}{c}\text { Günlük } \\
\text { ayakta } \\
\text { muayene } \\
\text { sayısındaki } \\
\text { azlık }\end{array}$ & $\begin{array}{c}\text { Yatan } \\
\text { günlük } \\
\text { hasta } \\
\text { sayısındaki } \\
\text { azlık }\end{array}$ & $\begin{array}{c}\text { Ameliyat } \\
\text { sayısındaki } \\
\text { azlık }\end{array}$ \\
\hline 1) & Acil ve İlkyardım & 1 & 0 & 0 & 0 & 0 & 0 & 0 & \# \\
\hline 2) & Anesteziyoloji & 0,574 & $-42,5$ & \# & $-52,5$ & $-51,5$ & 0 & 413,3 & 186,9 \\
\hline 3) & Beyin Cerrahi & 1 & 0 & $\#$ & 0 & 0 & 0 & 0 & 0 \\
\hline 4) & Çocuk Cerrahisi ve Ürolojisi & 1 & 0 & \# & 0 & 0 & 0 & 0 & 0 \\
\hline 5) & Çocuk Sağlı̆̆ 1 ve Hastalıkları & 0,968 & $-3,1$ & $-36,4$ & $-41,4$ & $-21,5$ & 0 & 24,6 & $\#$ \\
\hline 6$)$ & Dermatoloji & 1 & 0 & 0 & 0 & 0 & 0 & 0 & $\#$ \\
\hline 7) & Enfeksiyon Hastalıkları & 0,5 & -50 & -50 & -50 & $-54,6$ & 34,6 & 0 & \# \\
\hline 8) & Fizik Tedavi ve Rehabilitasyon & 0,744 & $-25,5$ & $-36,2$ & $-25,5$ & $-57,7$ & 0 & 28 & $\#$ \\
\hline 9) & Genel Cerrahi & 0,531 & $-46,8$ & $-46,8$ & $-46,8$ & $-46,8$ & 0 & 0 & 0 \\
\hline 10) & Göğüs Cerrahi & 0,8 & -20 & $-33,3$ & $-47,3$ & -20 & 205,1 & 2,1 & 0 \\
\hline 11) & Göğüs Hastalıkları & 1 & 0 & $-33,8$ & $-67,1$ & $-86,8$ & 16,6 & 0 & \# \\
\hline 12) & Göz Hastalıkları & 1 & 0 & 0 & 0 & 0 & 0 & 0 & 0 \\
\hline 13) & İç Hastalıkları & 1 & 0 & 0 & 0 & 0 & 0 & 0 & \# \\
\hline 14) & Kadın Hastalıkları ve Doğum & 0,907 & $-9,2$ & $-9,2$ & $-30,2$ & $-9,2$ & 0 & 0 & 0 \\
\hline 15) & Kalp Damar Cerrahi & 0,8 & -20 & -20 & $-82,4$ & $-65,1$ & 8,3 & 0,6 & 0 \\
\hline 16) & Kardiyoloji & 0,71 & $-29,9$ & $-29,9$ & $-38,6$ & $-58,3$ & 0 & 0 & \# \\
\hline 17) & Kulak Burun Boğaz & 0,9 & $-9,9$ & $-9,9$ & $-9,9$ & $-50,1$ & 0 & 35,3 & 0 \\
\hline 18) & Nöroloji & 0,432 & $-56,7$ & $-56,7$ & $-56,7$ & $-65,9$ & 0 & 0 & 36283,2 \\
\hline 19) & Nükleer Tıp & 1 & 0 & \# & \# & 0 & 0 & 0 & \# \\
\hline 20) & Ortopedi ve Travmatoloji & 0,625 & $-37,4$ & $-37,5$ & $-37,4$ & $-60,5$ & 0 & 0 & 0 \\
\hline 21) & Plastik Rekons ve Estetik Cerrahi & 1 & 0 & 0 & 0 & 0 & 0 & 0 & 0 \\
\hline 22) & Psikiyatri & 0,8 & -20 & $-75,5$ & $-52,2$ & $-76,1$ & 0 & 285,7 & \# \\
\hline 23) & Radyasyon Onkoloji & 1 & 0 & 0 & 0 & 0 & 0 & 0 & $\#$ \\
\hline 24) & Radyoloji & 1 & 0 & 0 & \# & 0 & 0 & 0 & $\#$ \\
\hline 25) & T1bbi Biyokimya & 0,666 & $-33,3$ & $-33,3$ & -100 & \# & 851,4 & $\#$ & $\#$ \\
\hline 26) & Tibbi Genetik/Pediatri & 1 & 0 & 0 & \# & \# & 0 & 0 & \# \\
\hline 27) & Üroloji & 1 & 0 & 0 & 0 & 0 & 0 & 0 & 0 \\
\hline
\end{tabular}


Tablo II. Anabilim dalları için BCC çıktı yönlü etkinlik değerleri ve girdi-çıktıların artık değerleri

Table II. BCC output-oriented efficiency values and residual values of input-outputs for departments

\begin{tabular}{|c|c|c|c|c|c|c|c|c|c|}
\hline & Anabilim dalları & $\begin{array}{c}\text { Etkinlik } \\
\text { skoru }\end{array}$ & $\begin{array}{c}\text { Öğretim } \\
\text { üyesi ve } \\
\text { öğretim } \\
\text { görevlisi } \\
\text { sayısındaki } \\
\text { fazlalık } \\
\end{array}$ & $\begin{array}{l}\text { Asistan Dr. } \\
\text { sayısındaki } \\
\text { fazlalık }\end{array}$ & $\begin{array}{c}\text { Hasta } \\
\text { bakıcı } \\
\text { sayısındaki } \\
\text { fazlalık }\end{array}$ & $\begin{array}{c}\text { Hemşire } \\
\text { sayısı } \\
\text { sayısındaki } \\
\text { fazlalık }\end{array}$ & $\begin{array}{c}\text { Günlük } \\
\text { ayakta } \\
\text { muayene } \\
\text { sayısındaki } \\
\text { azlık }\end{array}$ & $\begin{array}{c}\text { Yatan } \\
\text { günlük } \\
\text { hasta } \\
\text { sayısındaki } \\
\text { azlık }\end{array}$ & $\begin{array}{c}\text { Ameliyat sayısındaki } \\
\text { azlık }\end{array}$ \\
\hline 1) & Acil ve İlkyardım & 1 & 0 & 0 & 0 & 0 & 0 & 0 & $\#$ \\
\hline 2) & Anesteziyoloji & 0,941 & -40 & \# & -50 & -50 & 6,2 & 428,9 & 191,5 \\
\hline 3) & Beyin Cerrahi & 1 & 0 & \# & 0 & 0 & 0 & 0 & 0 \\
\hline 4) & Çocuk Cerrahisi ve Ürolojisi & 1 & 0 & \# & 0 & 0 & 0 & 0 & 0 \\
\hline 5) & Çocuk Sağlığı ve Hastalıkları & 0,985 & 0 & $-34,8$ & $-40,3$ & $-18,9$ & 1,4 & 28,4 & \# \\
\hline 6$)$ & Dermatoloji & 1 & 0 & 0 & 0 & 0 & 0 & 0 & \# \\
\hline 7) & Enfeksiyon Hastalıkları & 0,436 & 0 & 0 & 0 & 0 & 150 & 129 & \# \\
\hline 8) & Fizik Tedavi ve Rehabilitasyon & 0,794 & 0 & 0 & 0 & $-44,4$ & 25,8 & 141,5 & \# \\
\hline 9) & Genel Cerrahi & 0,681 & $-46,6$ & 0 & $-17,5$ & $-17,2$ & 46,6 & 46,6 & 46,6 \\
\hline 10) & Göğüs Cerrahi & 0,340 & 0 & 0 & $-22,2$ & 0 & 252,2 & 193,5 & 193,5 \\
\hline 11) & Göğüs Hastalıkları & 0,773 & 0 & $-16,6$ & -50 & -80 & 29,2 & 52,2 & \# \\
\hline 12) & Göz Hastalıkları & 1 & 0 & 0 & 0 & 0 & 0 & 0 & 0 \\
\hline 13) & İç Hastalıkları & 1 & 0 & 0 & 0 & 0 & 0 & 0 & \# \\
\hline 14) & Kadın Hastalıkları ve Doğum & 0,913 & 0 & 0 & $-22,8$ & 0 & 9,4 & 9,4 & 9,4 \\
\hline 15) & Kalp Damar Cerrahi & 0,720 & 0 & 0 & $-67,2$ & $-47,8$ & 38,7 & 54,9 & 38,7 \\
\hline 16) & Kardiyoloji & 0,732 & $-1,3$ & 0 & $-1,7$ & $-15,7$ & 36,4 & 36,4 & \# \\
\hline 17) & Kulak Burun Boğaz & 0,927 & 0 & 0 & 0 & -43 & 7,7 & 64,3 & 7,7 \\
\hline 18) & Nöroloji & 0,497 & $-45,7$ & 0 & 0 & $-30,1$ & 101 & 101 & 48461,5 \\
\hline 19) & Nükleer Tıp & 1 & 0 & \# & \# & 0 & 0 & 0 & \# \\
\hline 20) & Ortopedi ve Travmatoloji & 0,669 & 0 & 0 & 0 & $-23,3$ & 49,3 & 83,8 & 49,3 \\
\hline 21) & Plastik Rekons ve Estetik Cerrahi & 1 & 0 & 0 & 0 & 0 & 0 & 0 & 0 \\
\hline 22) & Psikiyatri & 0,578 & 0 & $-55,1$ & 0 & $-12,2$ & 72,7 & 364,6 & \# \\
\hline 23) & Radyasyon Onkoloji & 1 & 0 & 0 & 0 & 0 & 0 & 0 & \# \\
\hline 24) & Radyoloji & 1 & 0 & 0 & \# & 0 & 0 & 0 & \# \\
\hline 25) & Tibbi Biyokimya & 0,105 & $-33,3$ & $-33,3$ & -100 & \# & 851,4 & \# & \# \\
\hline 26) & Tibbi Genetik/Pediatri & 1 & 0 & 0 & \# & \# & 0 & 0 & \# \\
\hline 27) & Üroloji & 1 & 0 & 0 & 0 & 0 & 0 & 0 & 0 \\
\hline
\end{tabular}


Tablo III. Anabilim dalları için CCR girdi-yönlü etkinlik değerleri ve girdi-çıktıların artık değerleri

Table III. CCR input-oriented efficiency values and residual values of input-outputs for departments

\begin{tabular}{|c|c|c|c|c|c|c|c|c|c|}
\hline & Anabilim dalları & $\begin{array}{c}\text { Etkinlik } \\
\text { skoru }\end{array}$ & $\begin{array}{c}\text { Öğretim } \\
\text { üyesi ve } \\
\text { öğretim } \\
\text { görevlisi } \\
\text { sayısındaki } \\
\text { fazlalık }\end{array}$ & $\begin{array}{l}\text { Asistan Dr. } \\
\text { sayısındaki } \\
\text { fazlalık }\end{array}$ & $\begin{array}{c}\text { Hasta } \\
\text { bakıcı } \\
\text { sayısındaki } \\
\text { fazlalık }\end{array}$ & $\begin{array}{l}\text { Hemşire } \\
\text { sayısı } \\
\text { sayısındaki } \\
\text { fazlalık }\end{array}$ & $\begin{array}{c}\text { Günlük ayakta } \\
\text { muayene } \\
\text { sayısındaki } \\
\text { azlık }\end{array}$ & $\begin{array}{c}\text { Yatan günlük } \\
\text { hasta } \\
\text { sayısındaki } \\
\text { azlık }\end{array}$ & $\begin{array}{c}\text { Ameliyat } \\
\text { sayısındaki } \\
\text { azlık }\end{array}$ \\
\hline 1) & Acil ve İlkyardım & 1 & 0 & 0 & 0 & 0 & 0 & 0 & \# \\
\hline 2) & Anesteziyoloji & 0,564 & $-43,5$ & $\#$ & $-52,9$ & $-52,9$ & 0 & 397,9 & 174,4 \\
\hline 3) & Beyin Cerrahi & 1 & 0 & $\#$ & 0 & 0 & 0 & 0 & 0 \\
\hline 4) & Çocuk Cerrahisi ve Ürolojisi & 1 & 0 & \# & 0 & 0 & 0 & 0 & 0 \\
\hline 5) & Çocuk Sağlığ 1 ve Hastalıkları & 0,712 & $-28,7$ & $-38,9$ & $-28,7$ & -43 & 37,5 & 0 & \# \\
\hline 6$)$ & Dermatoloji & 1 & 0 & 0 & 0 & 0 & 0 & 0 & $\#$ \\
\hline 7) & Enfeksiyon Hastalıkları & 0,379 & -62 & -62 & -62 & $-66,6$ & 1,4 & 0 & $\#$ \\
\hline 8) & Fizik Tedavi ve Rehabilitasyon & 0,722 & $-27,7$ & $-43,1$ & $-27,7$ & $-58,6$ & 0 & 0 & \# \\
\hline 9) & Genel Cerrahi & 0,492 & $-50,7$ & $-50,7$ & $-51,8$ & $-56,1$ & 0 & 0 & 0 \\
\hline 10) & Göğüs Cerrahi & 0,331 & $-66,8$ & $-66,8$ & -73 & $-66,8$ & 26 & 0 & 0 \\
\hline 11) & Göğüs Hastalıkları & 0,622 & $-37,7$ & $-37,7$ & $-54,1$ & $-73,7$ & 0 & 0 & \# \\
\hline 12) & Göz Hastalıkları & 1 & 0 & 0 & 0 & 0 & 0 & 0 & 0 \\
\hline 13) & İç Hastalıkları & 1 & 0 & 0 & 0 & 0 & 0 & 0 & \# \\
\hline 14) & Kadın Hastalıkları ve Doğum & 0,887 & $-11,2$ & $-11,2$ & $-38,1$ & $-26,7$ & 0 & 0 & 0 \\
\hline 15) & Kalp Damar Cerrahi & 0,701 & $-29,8$ & $-29,8$ & $-76,5$ & -67 & 0 & 0 & 0 \\
\hline 16) & Kardiyoloji & 0,696 & $-30,3$ & $-30,3$ & $-40,4$ & $-61,7$ & 0 & 0 & \# \\
\hline 17) & Kulak Burun Boğaz & 0,873 & $-12,6$ & $-17,9$ & $-12,6$ & $-52,4$ & 0 & 0 & 0 \\
\hline 18) & Nöroloji & 0,428 & $-57,1$ & $-57,1$ & $-57,1$ & $-69,3$ & 0 & 0 & 26730,2 \\
\hline 19) & Nükleer Tıp & 1 & 0 & \# & \# & 0 & 0 & 0 & \# \\
\hline 20) & Ortopedi ve Travmatoloji & 0,624 & $-37,5$ & $-37,5$ & $-37,5$ & $-60,4$ & 0 & 0 & 0 \\
\hline 21) & Plastik Rekons ve Estetik Cerrahi & 1 & 0 & 0 & 0 & 0 & 0 & 0 & 0 \\
\hline 22) & Psikiyatri & 0,558 & $-44,1$ & $-77,7$ & $-44,1$ & $-50,7$ & 0 & 80,9 & \# \\
\hline 23) & Radyasyon Onkoloji & 1 & 0 & 0 & 0 & 0 & 0 & 0 & \# \\
\hline 24) & Radyoloji & 1 & 0 & 0 & \# & 0 & 0 & 0 & $\#$ \\
\hline 25) & T1bbi Biyokimya & 0,07 & $-92,9$ & $-92,9$ & -100 & \# & 0 & \# & $\#$ \\
\hline 26) & T1bbi Genetik/Pediatri & 1 & 0 & 0 & \# & \# & 0 & 0 & $\#$ \\
\hline 27) & Üroloji & 0,897 & $-10,3$ & $-10,2$ & $-10,2$ & 10,2 & 17,3 & 0 & 0 \\
\hline
\end{tabular}


Tablo IV. Anabilim dalları için CCR çıktı yönlü etkinlik değerleri ve girdi-çıktıların artık değerleri

Table IV. CCR output-oriented efficiency values and residual values of input-outputs for departments

\begin{tabular}{|c|c|c|c|c|c|c|c|c|c|}
\hline & Anabilim dalları & $\begin{array}{c}\text { Etkinlik } \\
\text { skoru }\end{array}$ & $\begin{array}{c}\text { Öğretim } \\
\text { üyesi ve } \\
\text { öğretim } \\
\text { görevlisi } \\
\text { sayısındaki } \\
\text { fazlalık } \\
\end{array}$ & $\begin{array}{l}\text { Asistan Dr. } \\
\text { sayısındaki } \\
\text { fazlalık }\end{array}$ & $\begin{array}{l}\text { Hasta bakıcı } \\
\text { sayısındaki } \\
\text { fazlalık }\end{array}$ & $\begin{array}{c}\text { Hemşire } \\
\text { sayısı } \\
\text { sayısındaki } \\
\text { fazlalık }\end{array}$ & $\begin{array}{c}\text { Günlük } \\
\text { ayakta } \\
\text { muayene } \\
\text { sayısındaki } \\
\text { azlık }\end{array}$ & $\begin{array}{c}\text { Yatan } \\
\text { günlük } \\
\text { hasta } \\
\text { sayısındaki } \\
\text { azlık }\end{array}$ & $\begin{array}{c}\text { Ameliyat } \\
\text { sayısındaki } \\
\text { azlık }\end{array}$ \\
\hline 1) & Acil ve İlkyardım & 1 & 0 & 0 & 0 & 0 & 0 & 0 & $\#$ \\
\hline 2) & Anesteziyoloji & 0,564 & 0 & \# & $-16,6$ & $-16,6$ & 77 & 781,5 & 385,8 \\
\hline 3) & Beyin Cerrahi & 1 & 0 & $\#$ & 0 & 0 & 0 & 0 & 0 \\
\hline 4) & Çocuk Cerrahisi ve Ürolojisi & 1 & 0 & \# & 0 & 0 & 0 & 0 & 0 \\
\hline 5) & Çocuk Sağlığı ve Hastalıkları & 0,712 & 0 & $-14,2$ & 0 & $-20,1$ & 92,9 & 40,3 & \# \\
\hline 6$)$ & Dermatoloji & 1 & 0 & 0 & 0 & 0 & 0 & 0 & $\#$ \\
\hline 7) & Enfeksiyon Hastalıkları & 0,379 & 0 & 0 & 0 & $-11,9$ & 167,5 & 163,6 & \# \\
\hline 8) & Fizik Tedavi ve Rehabilitasyon & 0,722 & 0 & $-21,2$ & 0 & $-42,7$ & 38,4 & 38,4 & \# \\
\hline 9) & Genel Cerrahi & 0,492 & 0 & 0 & $-2,2$ & $-10,9$ & 102,9 & 102,9 & 102,9 \\
\hline 10) & Göğüs Cerrahi & 0,331 & 0 & 0 & $-18,4$ & 0 & 280,6 & 202 & 202 \\
\hline 11) & Göğüs Hastalıkları & 0,622 & 0 & 0 & $-26,3$ & $-57,8$ & 60,6 & 60,6 & \# \\
\hline 12) & Göz Hastalıkları & 1 & 0 & 0 & 0 & 0 & 0 & 0 & 0 \\
\hline 13) & İç Hastalıkları & 1 & 0 & 0 & 0 & 0 & 0 & 0 & \# \\
\hline 14) & Kadın Hastalıkları ve Doğum & 0,887 & 0 & 0 & $-30,2$ & $-17,4$ & 12,6 & 12,6 & 12,6 \\
\hline 15$)$ & Kalp Damar Cerrahi & 0,701 & 0 & 0 & $-66,6$ & $-52,9$ & 42 & 42,5 & 42,5 \\
\hline 16) & Kardiyoloji & 0,696 & 0 & 0 & $-14,5$ & $-45,9$ & 43,5 & 43,5 & \# \\
\hline 17) & Kulak Burun Boğaz & 0,873 & 0 & $-6,8$ & 0 & $-45,5$ & 14,5 & 14,5 & 14,5 \\
\hline 18) & Nöroloji & 0,428 & 0 & 0 & 0 & $-28,4$ & 133,3 & 133,3 & 62507,8 \\
\hline 19) & Nükleer Tıp & 1 & 0 & \# & \# & 0 & 0 & 0 & \# \\
\hline 20) & Ortopedi ve Travmatoloji & 0,624 & 0 & 0 & 0 & $-36,7$ & 60 & 60 & 60 \\
\hline 21) & Plastik Rekons ve Estetik Cerrahi & 1 & 0 & 0 & 0 & 0 & 0 & 0 & 0 \\
\hline 22) & Psikiyatri & 0,555 & 0 & $-60,1$ & 0 & $-11,7$ & 79 & 223,9 & \# \\
\hline 23) & Radyasyon Onkoloji & 1 & 0 & 0 & 0 & 0 & 0 & 0 & \# \\
\hline 24) & Radyoloji & 1 & 0 & 0 & \# & 0 & 0 & 0 & \# \\
\hline 25) & T1bbi Biyokimya & 0,07 & 0 & 0 & -100 & $\#$ & 1327,1 & $\#$ & $\#$ \\
\hline 26) & T1bbi Genetik/Pediatri & 1 & 0 & 0 & \# & \# & 0 & 0 & \# \\
\hline 27) & Üroloji & 0,897 & $-0,1$ & 0 & 0 & 0 & 30,7 & 11,4 & 11,4 \\
\hline
\end{tabular}

